\title{
Development of a quantitative competitive reverse transcriptase polymerase chain reaction for the quantification of growth hormone gene expression in pigs
}

\author{
Maurício Machaim Franco ${ }^{1,2}$, Juliana Franco Almeida ${ }^{1}$, Guilherme Rocha Lino de Souza ${ }^{1}$, \\ Robson Carlos Antunes ${ }^{1}$ and Luiz Ricardo Goulart ${ }^{1}$ \\ ${ }^{1}$ Laboratório de Genética Molecular, Instituto de Genética e Bioquímica, \\ Universidade Federal de Uberlândia, Uberlândia, MG, Brazil. \\ ${ }^{2}$ Laboratório de Genética Molecular Animal, Embrapa Recursos Genéticos e Biotecnologia, \\ Brasilia, DF, Brazil.
}

\begin{abstract}
After the advent of the genome projects, followed by the discovery of DNA polymorphisms, basic understanding of gene expression is the next focus to explain the association between polymorphisms and the level of gene expression, as well as to demonstrate the interaction among genes. Among the various techniques for the investigation of transcriptional profiling involving patterns of gene expression, quantitative PCR is the simplest analytical laboratory technique. The objective of this work was to analyze two strategies of a competitive PCR technique for the quantification of the pig growth hormone $(\mathrm{GH})$ gene expression. A pair of primers was designed targeting exons 3 and 5, and two competitive PCR strategies were performed, one utilizing a specific amplicon as a competitor, and the other utilizing a low-stringency PCR amplicon as a competitor. The latter strategy proved to be easier and more efficient, offering an accessible tool that can be used in any kind of competitive reaction, facilitating the study of gene expression patterns for both genetics and diagnostics of infectious diseases.
\end{abstract}

Key words: pig, GH gene, gene expression, RT-PCR.

Received: June 6, 2002; accepted: November 8, 2002.

\section{Introduction}

The sequencing of genomes opens a new perspective to the functional studies of various genes. Among the most important technologies in use, the recent application of microarrays allows to study more complex gene interactions, although requiring heavy investments and sophisticated computational tools, and the methods used to analyze the data can have a great influence on the interpretation of the results.

On the other hand, quantitative PCR and its technical variations focus on the individual analysis of genes, also presenting the advantage of great sensitivity, easy performance and low cost. The simplest way of identifying genes of potential interest is to study the transcriptional profiling after detection of gene polymorphisms, in order to find an association between them. However, because of many interactions among genes, polymorphisms may have no ef-

Send correspondence to Maurício Machaim Franco. Embrapa Recursos Genéticos e Biotecnologia, Avenida W/5 Norte Final, Prédio Biotecnologia, Sala 7, 70770-900 Brasília, DF, Brazil. E-mail: mfranco@ cenargen.embrapa.br. fect on a given gene expression profile, due to confounding factors, which block the true effect of SNPs (single nucleotide polymorphisms) in the final gene expression of a phenotype. Therefore, the analysis of differential gene expression profiles may be done regardless of observed polymorphisms, demonstrating their biological function and relevance.

Recently, several modifications in quantitative PCR have been described, and the most important of them is probably the competitive PCR (Gilliland et al., 1990), which uses a mixture of a genomic competitor template and a target RNA (gene) sample, to determine its expression pattern. This strategy allows an accurate identification of the number of transcribed molecules, in addition to the concomitant verification of successful PCR reactions and the detection of false-negatives.

The growth hormone gene of swine is a single-copy gene, localized on chromosome 12, and its great influence on economically important traits has led to a variety of studies regarding its molecular constitution (Schellander $e t$ al. 1994). 
The pig GH gene, also named pGH (porcine growth hormone) or somatotropin, was isolated and characterized by Vize and Wells in 1987, and the association of this gene with quantitative traits has been widely investigated ever since.

Nielsen and Larsen (1991) studied RFLPs (restriction fragment length polymorphisms) of the GH gene in Danish and Swedish pig populations, and found $\mathrm{pGH}$ polymorphisms with DraI and TaqI enzymes. They demonstrated that there are alterations in the blood concentration of pGH, suggesting genetic differences at the GH locus or at other loci which codify proteins involved in the GH gene expression. Nielsen et al. (1995) used DSCP (doublestrand conformation polymorphism) markers at the pGH promoter region, and found an association between gene polymorphisms and alterations of plasma GH levels, leading them to suggest that this gene may be a QTL (quantitative trait locus) for $\mathrm{GH}$ levels.

The purpose of this work was to analyze two strategies of a competitive RT-PCR technique for the quantification of the pig GH gene expression.

\section{Material and Methods}

\section{Genomic DNA extraction}

The genomic DNA used as a template for the optimization and template competitor production was obtained from blood samples by adding $1 \mathrm{~mL}$ of lysis buffer [20 mM Tris- $\mathrm{HCl} \mathrm{pH}$ 7.5, $5 \mathrm{mM}$ ethylene-diamine-tetracetic acid (EDTA) pH 7.5, $640 \mathrm{mM}$ sucrose, $10 \mathrm{mM} \mathrm{MgCl}_{2}, 4 \%$ Triton $\mathrm{X}-100]$ to $500 \mu \mathrm{L}$ of leucocytes, and kept on ice for $10 \mathrm{~min}$. Lysed cells were precipitated (white pellet) by centrifugation at $7200 \mathrm{G}$ for $1 \mathrm{~min}$ at $4{ }^{\circ} \mathrm{C}$, followed by two or more washes with lysis buffer diluted $1: 1 \mathrm{v} / \mathrm{v}$ in water. The pellet was submitted to digestion by $10 \mu \mathrm{L}$ of proteinase $\mathrm{K}(10 \mathrm{mg} / \mathrm{mL})$ and $200 \mu \mathrm{L}$ PK buffer (10 mM Tris-HCl pH 7.5, 1 mM EDTA $\mathrm{pH} 7.5$ and $1 \%$ sarkosyl), and incubated overnight at $50{ }^{\circ} \mathrm{C}$. After overnight incubation, $500 \mu \mathrm{L}$ of $8 \mathrm{M}$ guanidine isothiocyanate $/ 0.49 \mathrm{M}$ ammonium acetate were added to the digestion solution and shaken for $1 \mathrm{~h}$ at room temperature to dissolve the pellet. The DNA was precipitated with $800 \mu \mathrm{L}$ of $100 \%$ isopropanol, centrifuged at $7200 \mathrm{G}$ for $10 \mathrm{~min}$, and the supernatant was discarded. Two more washes with $60 \%$ isopropanol were performed, followed by centrifugation at $7200 \mathrm{G}$ for $2 \mathrm{~min}$. The DNA was dried and then re-dissolved in $0.2 \mathrm{~mL}$ of TE (10 mM Tris-HCl pH 7.5 and $1 \mathrm{mM}$ EDTA), followed by incubation at $65^{\circ} \mathrm{C}$ for $1 \mathrm{~h}$ for complete dilution.

\section{Optimization of the PCR conditions and production of genomic and low-stringency competitor amplicons}

The primers were designed using the Primer Designer - version 2.0 Scientific \& Educational Software Program (copyright 1990,91), according to the published GH gene sequence (Vize and Wells, 1987). The primer sequences were: 5'-CGATCGCAGAGGTACTCCATCCAGAA-3' (forward) and 5'-CGATCGTATGTCTCAGCCTTGTGC AG-3' (reverse), localized in exons 3 and 5, respectively.

Since the forward primer anneals in exon 3 , and the reverse primer in exon 5 of the pGH gene, genomic DNA and cDNA can be co-amplified with the same primers, but with different expected sizes.

Different concentrations of $\mathrm{MgCl}_{2}(1.5$ and $2.0 \mathrm{mM})$ and $25 \mu \mathrm{M} \mathrm{TMAC}$ (tetramethylammonium chloride) were used with 1.0 U of Taq DNA polymerase (Cenbiot Enzimas, Centro de Biotecnologia - UFRGS, Porto Alegre, Brazil), 1X PCR buffer, $400 \mu \mathrm{M}$ dNTP, $0.2 \mu \mathrm{M}$ of each antisense and sense primers and $150 \mathrm{ng}$ of genomic DNA, in a final volume of $20 \mu \mathrm{L}$ to optimize the specific amplification conditions of the GH gene, using genomic DNA as template. TMAC, a denaturant agent, was utilized to obtain a more specific reaction.

After preheating at $95{ }^{\circ} \mathrm{C}$ for 4 min, 35 amplification cycles were performed at $95^{\circ} \mathrm{C}$ for $30 \mathrm{~s}, 66^{\circ} \mathrm{C}$ for $40 \mathrm{~s}$ and $72{ }^{\circ} \mathrm{C}$ for $1 \mathrm{~min}$. Final incubation was performed at $72{ }^{\circ} \mathrm{C}$ for $10 \mathrm{~min}$.

The genomic amplicon was cut from the agarose gel, macerated, filtrated through a glass-wool plug by centrifugation at $6000 \mathrm{G}$, and collected in a $1.5 \mathrm{~mL}$ microtube. Purification was achieved by adding $2 \mu \mathrm{L}$ of $7.5 \mathrm{M}$ ammonium acetate and $2 \mu \mathrm{L}$ of glycogen $(10 \mathrm{mg} / \mathrm{mL})$ to a volume of $8 \mu \mathrm{L}$, that was then mixed and incubated with the same volume of $100 \%$ ethanol for $3 \mathrm{~h}$ at $-20{ }^{\circ} \mathrm{C}$. The DNA solution was centrifuged at $19000 \mathrm{G}$ for $5 \mathrm{~min}$, and the pellet was subsequently washed with $70 \%$ ethanol.

Another competitor template was obtained by means of a second strategy (Zimmermann and Mannhalter, 1996), using low-stringency PCR to obtain unspecific fragments using the same primers. After preheating at $95^{\circ} \mathrm{C}$ for $4 \mathrm{~min}$, 35 amplification cycles were performed at $95^{\circ} \mathrm{C}$ for $30 \mathrm{~s}$, $55^{\circ} \mathrm{C}$ for $40 \mathrm{~s}$, and $72{ }^{\circ} \mathrm{C}$ for $45 \mathrm{~s}$. Final incubation was performed at $72{ }^{\circ} \mathrm{C}$ for $4 \mathrm{~min}$. The PCR reaction conditions were: $1.0 \mathrm{U}$ of Taq DNA polymerase (Cenbiot Enzimas, Centro de Biotecnologia - UFRGS, Porto Alegre, Brazil), 1X PCR buffer, 1.5, 2.0, 2.5 and $3.0 \mathrm{mM} \mathrm{MgCl}_{2}, 400 \mu \mathrm{M}$ dNTP, $0.5 \mu \mathrm{M}$ of each of both primers, and $30 \mathrm{ng}$ of genomic DNA, in a final volume of $20 \mu \mathrm{L}$. After agarose gel electrophoresis, a 298-bp amplicon was chosen as competitor for the competitive RT-PCR. This low-stringency competitor amplicon was purified by using the same protocol as for the genomic amplicon.

All PCR products were submitted to 1.5\% agarose gel electrophoresis, stained with ethidium bromide, and photographed under UV illumination.

\section{RNA extraction and optimization of the RT-PCR conditions for amplification of the GH cDNA}

Total RNA was extracted from a pituitary gland, using Trizol Reagent (Gibco BRL), according to the manu- 
facturer's protocol, with a weight ratio of $1.5 \mathrm{~mL}$ Trizol/sample.

Conditions for GH cDNA amplification were optimized by using samples with different concentrations of total RNA $(1000,500,250,125,62.5,31.25,15.625$, and $7.8125 \mathrm{ng}), 0.08 \mu \mathrm{M}$ of each antisense and sense primers, mixed with the Ready-to-go ${ }^{\text {TM }}$ RT-PCR Beads kit (Amersham Pharmacia Biotech, Inc). The reverse transcription and PCR amplification reactions were subsequently performed under the following conditions: $42{ }^{\circ} \mathrm{C}$ for $30 \mathrm{~min}, 95^{\circ} \mathrm{C}$ for $5 \mathrm{~min}, 30$ cycles at $95^{\circ} \mathrm{C}$ for $30 \mathrm{~s}$, $66{ }^{\circ} \mathrm{C}$ for $40 \mathrm{~s}$, and $72{ }^{\circ} \mathrm{C}$ for $1 \mathrm{~min}$. Final incubation was performed at $72{ }^{\circ} \mathrm{C}$ for $10 \mathrm{~min}$.

The RT-PCR products were submitted to $1.5 \%$ agarose gel electrophoresis, stained with ethidium bromide, and photographed under UV illumination.

\section{Competitive RT-PCR}

For the competitive RT-PCR optimization, several concentrations $(100,10,8,6,4,2,1$, and $0.8 \mathrm{ng}$ ) of the purified amplicon (891-bp) were previously tested with a fixed concentration of $30 \mathrm{ng}$ of total RNA and $0.08 \mu \mathrm{M}$ of each primer. In view of the excessive amplification of the purified amplicon in the preliminary test, other concentrations $(10,2.5,0.625,0.156$, and $0.04 \mathrm{ng})$ were used for better resolution, and mixed with $75 \mathrm{ng}$ of total RNA (target) and $0.08 \mu \mathrm{M}$ of each primer. The reverse transcription and PCR amplification reactions were performed using the same conditions as described for the GH cDNA production.

Another competitive RT-PCR reaction was set up, with the 298-bp template as competitor, but with $10 \mathrm{ng}$ of total RNA (target), thirteen dilutions of the competitor template $(100,10,8,6,4,2,1,0.8,0.6,0.4,0.2,0.1$, and $0.01 \mathrm{ng}$ ), and $0.08 \mu \mathrm{M}$ of each primer. A similar reaction was also performed with a concentration of $20 \mathrm{ng}$ of total RNA (target), and eight competitor template dilutions ( 0.8 , $0.6,0.4,0.2,0.1,0.01,0.005$, and $0.001 \mathrm{ng}$ ). The reverse transcription and the PCR amplification reactions were performed at $42{ }^{\circ} \mathrm{C}$ for $30 \mathrm{~min}, 95^{\circ} \mathrm{C}$ for $5 \mathrm{~min}, 30$ cycles at $95^{\circ} \mathrm{C}$ for $30 \mathrm{~s}, 58^{\circ} \mathrm{C}$ for $40 \mathrm{~s}$, and $72^{\circ} \mathrm{C}$ for $1 \mathrm{~min}$. Final incubation was performed at $72{ }^{\circ} \mathrm{C}$ for $10 \mathrm{~min}$.

The total RNA samples used in these experiments were not treated with RNase-free DNaseI. However, a control procedure was performed with the same RNA samples in semi-quantitative RT-PCR reactions, to verify sample quality and to test genomic contamination. To this effect, PCR multiplex reactions were performed, using both $\mathrm{GH}$ and $\beta$-actin primers simultaneously, with total RNA without previous RT (reverse transcription). The reaction conditions were the same as described for the competitive RT-PCR with the low-stringency competitor (298-bp) and $25 \mathrm{ng}$ of total RNA. All competitive RT-PCR reactions were performed with the Ready-to-go ${ }^{\mathrm{TM}}$ RT-PCR Beads kit (Amersham Pharmacia Biotech, Inc), and the RT-PCR products were submitted to $1.5 \%$ agarose gel electrophore- sis, stained with ethidium bromide, and photographed under UV illumination.

\section{Reaction controls and normalization of samples with $\beta$-actin gene}

A pair of primers was also used to amplify a 264-bp fragment of the $\beta$-actin gene (Matteri and Carroll 1997), representing a constitutive gene. All reactions were performed under the same conditions as described for competitive RT-PCR with the 298-bp competitor. This control test was done to normalize samples, in view of their qualitative and quantitative differences after nucleic acid extraction, and to correct differential amplifications during reverse transcription. Negative controls (reaction components without DNA/RNA templates) were also performed for all experimental conditions, in order to control crosscontamination.

\section{Densitometric readings and statistical analysis}

After the optimization of the PCR and RT-PCR reactions, size determinations (base pairs) for the lowstringency competitor template and the quantification of gene expression were done by densitometry, using the ImageMaster $^{\mathrm{TM}}$ VDS Software version 2.0 (Pharmacia Biotech, Inc). The quantification of the GH gene expression was based on densitometric readings of the competitor amplicon at a known concentration (Gilliland et al. 1990). A linear regression analysis was performed to calculate the target RNA concentration, by utilizing Microsoft Excel 97 software.

\section{Results}

The expected sizes of the specific GH genomic DNA and the GH cDNA amplicons were, respectively, $891 \mathrm{bp}$ and $418 \mathrm{bp}$, including primer sequences, as showed in Figures 1 and 2. An increasing intensity of amplicons was observed, as the concentration of $\mathrm{MgCl}_{2}$ increased, or by adding $25 \mu \mathrm{M}$ TMAC with a smaller concentration of $\mathrm{MgCl}_{2}$; but all conditions produced good amplifications. Since there were no differences in amplicon quality, and

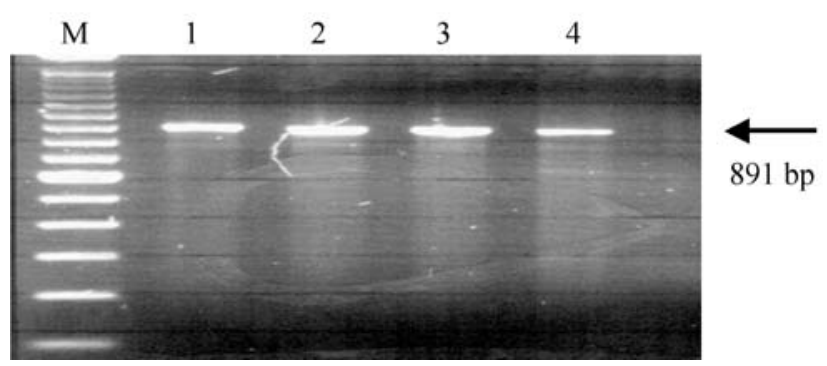

Figure 1 - GH genomic amplicons separated by 1.5\% agarose gel electrophoresis. Lane M: 100-bp DNA molecular weight markers; Lane 1: PCR product using $1.5 \mathrm{mM} \mathrm{MgCl}_{2}$; Lane 2: PCR product using $2.0 \mathrm{mM} \mathrm{MgCl}_{2}$; Lane 3: PCR product using $1.5 \mathrm{mM} \mathrm{MgCl}_{2}$ and $25 \mu \mathrm{M}$ TMAC; Lane 4: PCR product using $2.0 \mathrm{mM} \mathrm{MgCl}_{2}$ and $25 \mu \mathrm{M}$ TMAC. 


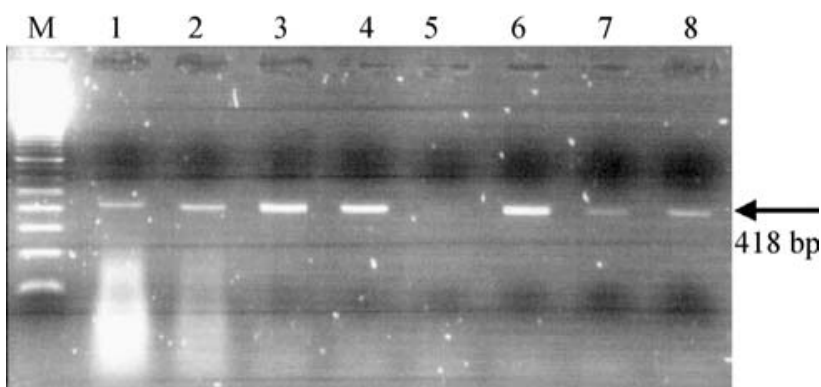

Figure 2 - GH cDNA amplicons separated by 1.5\% agarose gel electrophoresis. Lane M: 100-bp DNA molecular weight markers; Lanes 1-8: RT-PCR products using $1000 \mathrm{ng}, 500 \mathrm{ng}, 250 \mathrm{ng}, 125 \mathrm{ng}, 62.5 \mathrm{ng}$, $31.25 \mathrm{ng}, 15.625 \mathrm{ng}$, and $7.8125 \mathrm{ng}$ of total RNA as template. The 418-bp band represents the GH mRNA.

considering cost-effectiveness, the reaction conditions chosen were those shown in lane 1 (Figure 1), consisting of: 1.0 U Taq DNA polymerase (Cenbiot Enzymes, Centro de Biotecnologia - UFRGS, Porto Alegre, Brazil), 1X PCR buffer, $1.5 \mathrm{mM} \mathrm{MgCl} \mathrm{Mg}_{2}, 400 \mu \mathrm{M}$ dNTPs, $0.2 \mu \mathrm{M}$ of each antisense and sense primers, $150 \mathrm{ng}$ genomic DNA, in a final volume of $20 \mu \mathrm{L}$.

Figure 2 shows the results of the GH cDNA amplification optimization, using different concentrations of total RNA. The amplification pattern obtained was as expected; $1000 \mathrm{ng}$ of total RNA inhibited the target RNA due to its excess, and $7.8125 \mathrm{ng}$ were insufficient for a good amplification. Dilutions of $250 \mathrm{ng}$ to $31.25 \mathrm{ng}$ were adequate template concentrations to obtain good amplifications. As shown in Figure 2, with $62.5 \mathrm{ng}$ of RNA, there was no amplification; however, this may be due to a possible manipulation error during PCR mix or electrophoresis loading.

Figure 3 shows RT-PCR reactions carried out with RNA templates in a single test tube with both $\mathrm{GH}$ e $\beta$-actin primers. PCR reactions were also performed (lanes $2,4,6$, 8 , and 10) using total RNA as template, to check for genomic DNA contamination. No amplification was observed, demonstrating that the samples had no genomic DNA contaminants.

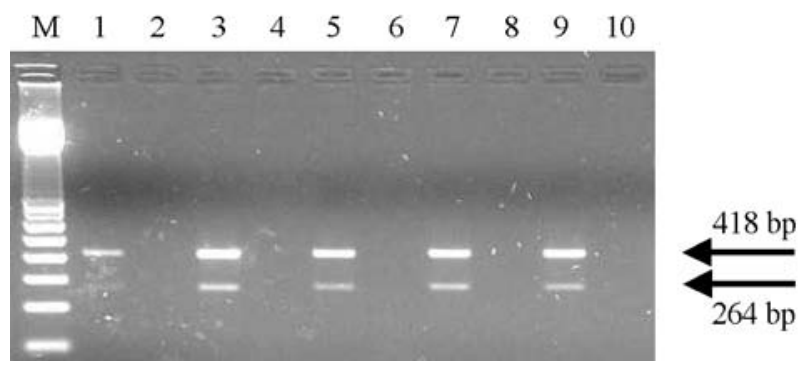

Figure 3 - GH cDNA and $\beta$-actin cDNA amplicons separated by $2 \%$ agarose gel electrophoresis. Lane M: 100-bp DNA molecular weight markers; Lanes 1, 3, 5, 7, and 9: RT-PCR reactions for the GH (418-bp) and $\beta$-actin (264-bp) genes with no RNase-free DNAseI-treated RNA; Lanes 2, 4, 6, 8, and 10: PCR reaction with total RNA as template for genomic DNA contamination control.
Using several concentrations of the 891-bp purified product as competitors, the competitive RT-PCR optimization showed the expected pattern of decreasing amplification, but the $30 \mathrm{ng}$ of total target RNA were insufficient to compete (Figure 4).

The results of the competitive RT-PCR using $75 \mathrm{ng}$ of total RNA are presented in Figure 5. Both genomic DNA and cDNA have similar sequences; therefore, they can form heteroduplexes of an intermediate molecular weight, which may impair analysis (Figure 5).

Figure 6 shows the low-stringency PCR results, indicating the 298-bp band that was excised and purified as the unspecific competitor template.

The results of the competitive RT-PCR using thirteen dilutions of the 298-bp competitor template and a fixed concentration (10 ng) of the target RNA are shown in Figure 7 , and the gDNA/cDNA ratio as a function of the known competitor template quantity is shown in Figure 8.

Due to the excessive amplification of the competitor and the weak amplification signal of the target RNA, another competitive RT-PCR reaction was set up with different competitor dilutions, using $20 \mathrm{ng}$ of total RNA (Figures 9 and 10).

Since the competitor template had a different size, and larger fragments exhibit greater intensity, the amplicon intensity (densitometry) of the larger band had to be adjusted by a correction factor obtained as follows: $\mathrm{F}=\mathrm{com}$ petitor DNA size in base pairs/cDNA size $=298 / 418=$ 0.7129 .

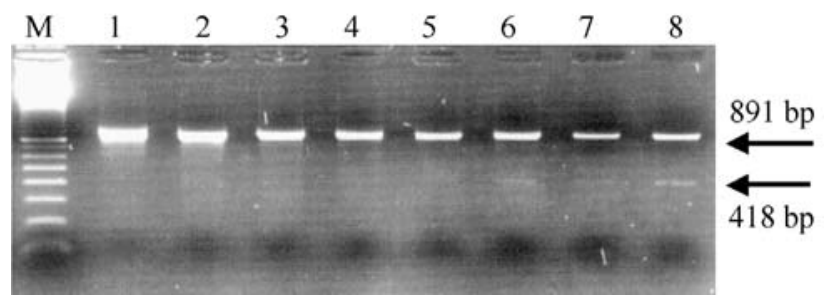

Figure 4 - GH genomic and cDNA amplicons separated in 1.5\% agarose gel electrophoresis. Lane M: 100-bp DNA molecular weight markers; Lanes 1-8: Competitive RT-PCR products using $100 \mathrm{ng}, 10 \mathrm{ng}, 8 \mathrm{ng}, 6 \mathrm{ng}$, $4 \mathrm{ng}, 2 \mathrm{ng}, 1 \mathrm{ng}$, and $0.8 \mathrm{ng}$ of 891-bp purified DNA as competitor template, and $30 \mathrm{ng}$ of total RNA. The 418-bp band represents the GH mRNA.

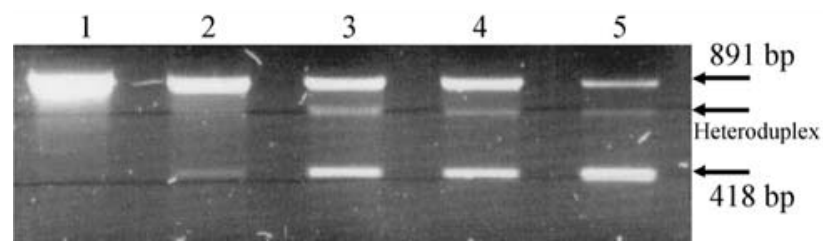

Figure 5 - GH genomic and cDNA amplicons separated by 1.5\% agarose gel electrophoresis. Lanes 1-5: Competitive RT-PCR products using $10 \mathrm{ng}, 2.5 \mathrm{ng}, 0.625 \mathrm{ng}, 0.156 \mathrm{ng}$, and $0.04 \mathrm{ng}$ of 891-bp purified DNA as competitor template, obtained from genomic DNA, and $75 \mathrm{ng}$ of total RNA. The 418-bp band represents the GH cDNA. The heteroduplex is showed between the 891-bp and 418-bp bands. 
$\begin{array}{llllllllllllll}\mathrm{M} & 1 & 2 & 3 & 4 & 5 & 6 & 7 & 8 & 9 & 10 & 11 & 12\end{array}$

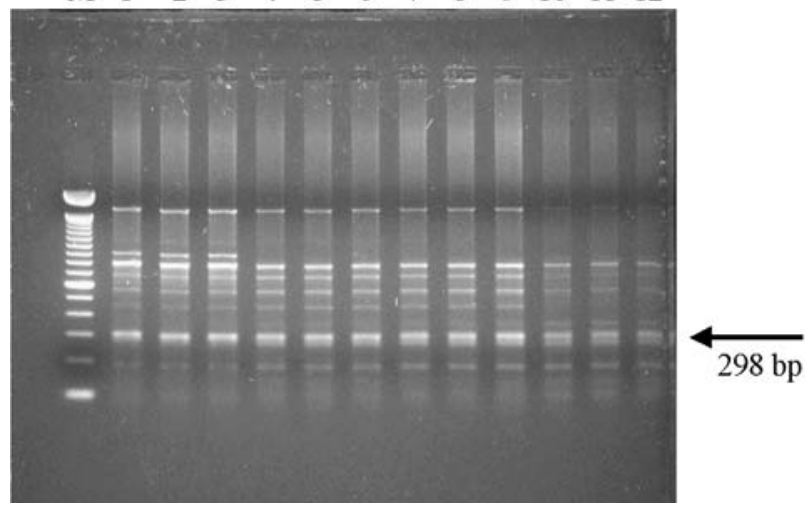

Figure 6 - Low-stringency amplicons separated by $1.5 \%$ agarose gel electrophoresis Lane M: 100-bp DNA molecular weight markers; Lanes 1-3: PCR products using $1.5 \mathrm{mM} \mathrm{MgCl}$; Lanes 4-6: PCR products using $2.0 \mathrm{mM} \mathrm{MgCl}$; Lanes 7-9: PCR products using $2.5 \mathrm{mM} \mathrm{MgCl} 2$; Lanes 10-12: PCR products using $3.0 \mathrm{mM} \mathrm{MgCl}_{2}$. The 298-bp band (arrow) was used as competitor template.

\section{$\begin{array}{llllllllllllll}\mathrm{M} & 1 & 2 & 3 & 4 & 5 & 6 & 7 & 8 & 9 & 10 & 11 & 12 & 13\end{array}$}

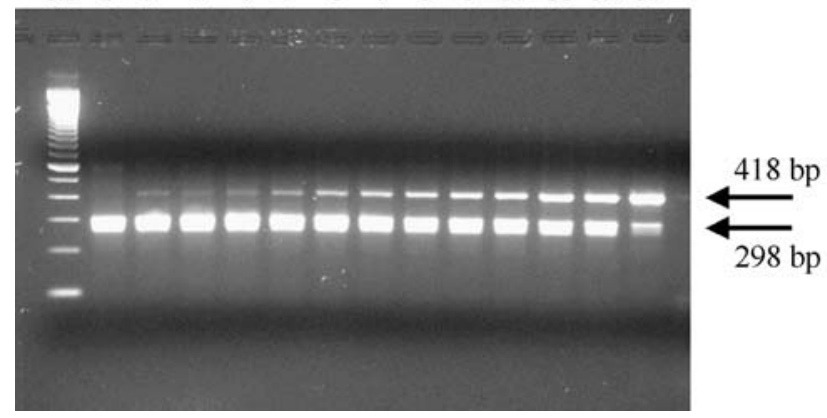

Figure 7 - GH cDNA and the unspecific competitor amplicons separated by $1.5 \%$ agarose gel electrophoresis Lane M: 100-bp DNA molecular weight markers; Lanes 1-13: Competitive RT-PCR products using $100 \mathrm{ng}$, $10 \mathrm{ng}, 8 \mathrm{ng}, 6 \mathrm{ng}, 4 \mathrm{ng}, 2 \mathrm{ng}, 1 \mathrm{ng}, 0.8 \mathrm{ng}, 0.6 \mathrm{ng}, 0.4 \mathrm{ng}, 0.2 \mathrm{ng}, 0.1 \mathrm{ng}$, and $0.01 \mathrm{ng}$ of 298-bp purified DNA as competitor template, and $10 \mathrm{ng}$ of total RNA. The 418-bp band represents the GH mRNA, and the 298-bp band the competitor obtained by low-stringency PCR.

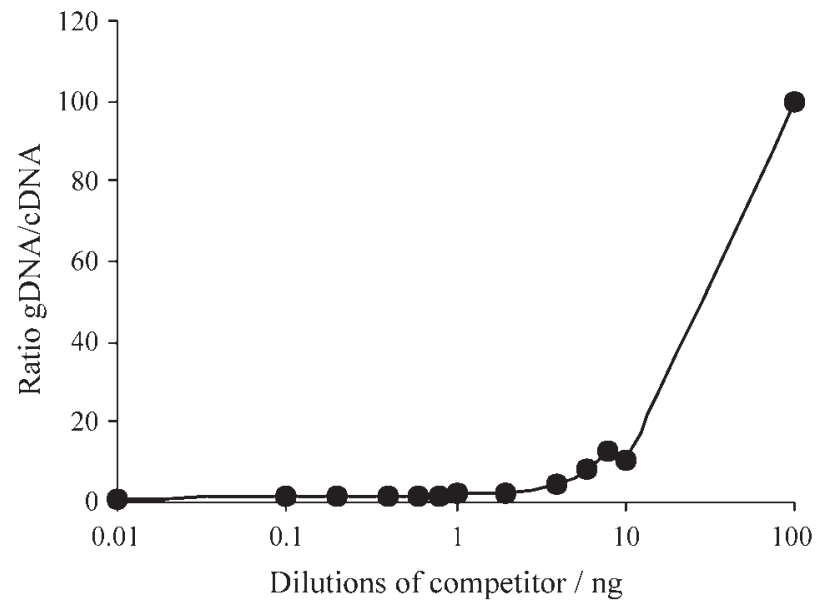

Figure 8 - Plotted gDNA/cDNA ratio after amplification, versus competitor dilutions added to mixture (100 ng, $10 \mathrm{ng}, 8 \mathrm{ng}, 6 \mathrm{ng}, 4 \mathrm{ng}, 2 \mathrm{ng}, 1 \mathrm{ng}$, $0.8 \mathrm{ng}, 0.6 \mathrm{ng}, 0.4 \mathrm{ng}, 0.2 \mathrm{ng}, 0.1 \mathrm{ng}$, and $0.01 \mathrm{ng}$ ).

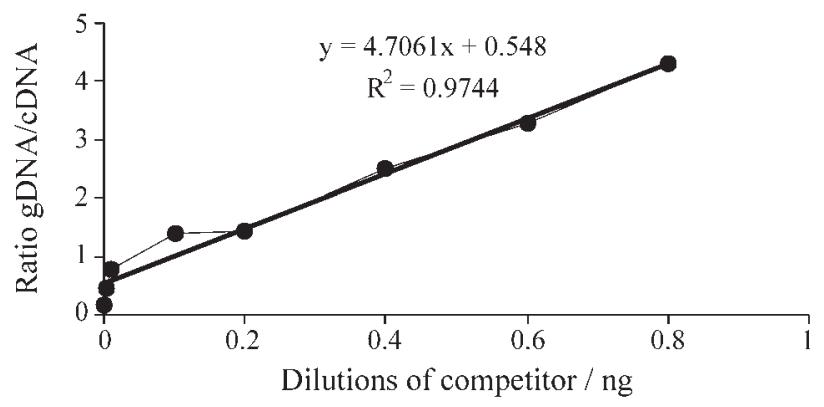

Figure 9 - Plotted gDNA/cDNA ratio after amplification, versus competitor dilutions added to mixture $(0.8 \mathrm{ng}, 0.6 \mathrm{ng}, 0.4 \mathrm{ng}, 0.2 \mathrm{ng}, 0.1 \mathrm{ng}$, $0.01 \mathrm{ng}, 0.005 \mathrm{ng}$, and $0.001 \mathrm{ng}$ ), and regression equation.

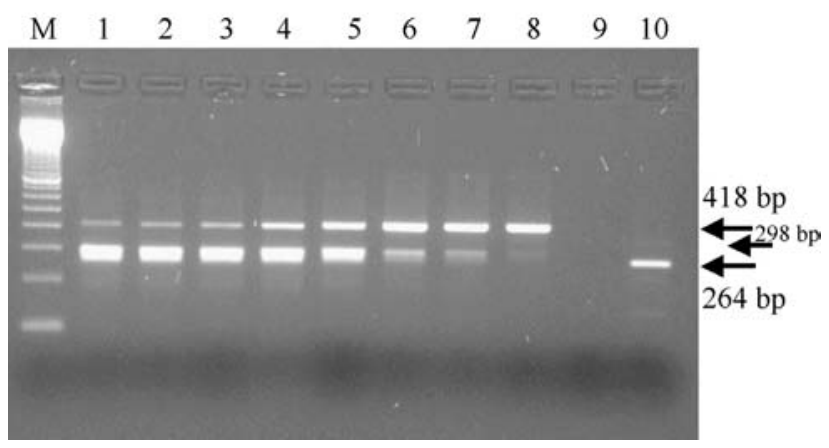

Figure 10 - GH cDNA, $\beta$-actin cDNA, and competitor amplicons separated by $1.5 \%$ agarose gel electrophoresis Lane M: 100-bp DNA molecular weight markers; Lanes 1-8: Competitive RT-PCR products using $0.8 \mathrm{ng}, 0.6 \mathrm{ng}, 0.4 \mathrm{ng}, 0.2 \mathrm{ng}, 0.1 \mathrm{ng}, 0.01 \mathrm{ng}, 0.005 \mathrm{ng}$, and $0.001 \mathrm{ng}$ of 298-bp purified DNA as competitor template, and $20 \mathrm{ng}$ of total RNA. The 264-bp band represents the $\beta$-actin cDNA used for quality control (Lane $10)$, and Lane 9 shows the negative control.

Figure 9 shows the gDNA/cDNA function curve, by using a fixed concentration of $20 \mathrm{ng}$ of total RNA, and a concentration range of the competitor, for which a linear relation was obtained ( 0.001 to $0.8 \mathrm{ng}$ of competitor template). The point of equivalence of target and competitor templates was not obtained. A 1:1 band ratio was expected for gDNA and cDNA, that would allow the determination of the gene concentration in this study. Although it was not possible to attain equivalence, a linear regression analysis was performed to calculate the target RNA concentration by utilizing Microsoft Excel 97 software.

The set values used for the linear regression analysis were obtained by densitometric readings of the competitive RT-PCR amplicons, as shown in Figure 10 (Equation: $\mathrm{Y}=4.7061 \mathrm{X}+0.548 ; \mathrm{R}^{2}=0.9744$ )

When ratio $\mathrm{Y}$ has the value 1, it means that the quantities of gDNA and cDNA are similar, and our final concentration of target RNA was $0.096 \mathrm{ng}$. If $1 \mu \mathrm{g}$ of a $1 \mathrm{~kb}$ fragment has $1.52 \mathrm{pmol}$ and $9.1 \times 10^{11}$ molecules, then $1 \mu \mathrm{g}$ of the $418 \mathrm{bp}$ fragment has $3.64 \mathrm{pmol}$ and $21.79 \times 10^{11} \mathrm{~mol}-$ ecules. Consequently, $0.096 \mathrm{ng}$ should have $2.092 \times 10^{8}$ molecules of GH mRNA in 20 ng of total RNA. 
When this technique is used to quantify gene expression, and quantities are to be compared between two or more animals, an internal control is necessary to normalize qualitative and quantitative differences of the RNA samples, and to check for the RT reaction efficiency, as shown in lane 10 for the $\beta$-actin gene (Figure 10). The negative controls, showed in lane 9, have all RT-PCR reagents, except RNA or DNA samples.

\section{Discussion}

It seemed likely that the concomitant amplification of the 891-bp genomic template and of the 418-bp cDNA would allow to quantify gene expression by using the competitive RT-PCR technique with DNA as a competitor (Gilliland et al. 1990). However, since the two fragments had very discrepant lengths, it was not possible to optimize the procedure with good reproducibility and, moreover, heteroduplexes were observed due to sequence similarities. This great difference between template sizes of the DNA competitor and the cDNA target with the primer designed for this experiment made the optimization of the competitive RT-PCR reaction difficult. Unfortunately, a primer flanking only one intron of the GH gene could not be obtained for this purpose.

The 418-bp band of the cDNA comprises a portion of exon 3, of exon 4, and of exon 5. In addition to these exons, the 891-bp fragment comprises introns 3 and 4; therefore, the exon regions are homologous, allowing heteroduplex formation. To prevent this, the number of PCR cycles should be reduced, or denaturing reagents that can separate partially homologous fragments should be used. None of these alternatives were tried, since this reaction has presented unstable results. For this reason, another competitor was produced.

Another competitor template, with a similar length and a different cDNA sequence, was obtained, to be efficiently amplified with the target cDNA. This product was obtained by a low-stringency reaction, allowing a reliable optimization, with good reproducibility, offering an excellent strategy for the quantification of pGH gene expression.

The results showed neither unspecific band amplification, nor heteroduplex formation, which had occurred when the 891-bp fragment was used as competitor template.

Figure 2 shows that RNA template dilutions from $250 \mathrm{ng}$ to $31.25 \mathrm{ng}$ were adequate to obtain good amplifications of the GH cDNA; however, these dilutions were optimized for the genomic DNA competitor (891-bp). Therefore, another RT-PCR reaction condition was optimized for the low-stringency competitor, with total RNA concentrations varying from 10 e $20 \mathrm{ng}$, resulting in good amplifications (Figures 7 and 10).

The competitive RT-PCR experiment was shown to be viable, fast and simple to perform by using a lowstringency DNA competitor, which is in agreement with Gilliland et al. (1990). The use of one-step RT-PCR with standardized reagents, and the use of an internal control, such as the $\beta$-actin gene, allowed us to use DNA as a competitor, assuring a good estimate of the gene expression.

This technique proved to be efficient for the quantification of specific mRNA, demonstrating that this methodology is suitable for routine studies of gene expression and diagnostics. Our results suggest that it is possible to use this methodology for any pair of primers, and for any gene, since the primers anneal within an exon or in different exons.

Special precaution is recommended regarding the size differences of the cDNA and the competitor template, since they need to be co-amplified with the same efficiency, in the same test tube.

\section{Acknowledgments}

We would like to thank Rezende Alimentos SA for the donation of biological specimens.

\section{References}

Gilliland G, Perrin S and Bunn HF (1990) Competitive PCR for quantitation of mRNA. In: Innis MA, Gelfand DH, Sninsky JJ and White, TJ (eds) PCR Protocols. A Guide to Methods and Applications. Academic Press Inc. San Diego, California 92101. Academic Press Limited, pp 60-69.

Matteri RL and Carroll JA (1997) Somatotroph function in the neonatal pig. Domestic Animal Endocrinology 14(4):241249.

Nielsen VH and Larsen NJ (1991) Restriction fragment length polymorphisms at the growth hormone gene in pigs. Animal Genetics 22:291-294.

Nielsen VH, Larsen NJ and Agergaad N (1995) Association of DNA polymorphism in the growth hormone gene with basal-plasma growth hormone concentration and production traits in pigs. Journal of Animal Breeding and Genetics 112:205-212.

Schellander K, Peli J, Kneissl F, Schmoll F and Mayr B (1994) Variation of the growth hormone gene in RYR 1 genotyped Austrian pig breeds. Journal of Animal Breeding and Genetics 111:162-166.

Vize PD and Wells JRE (1987) Isolation and characterization of the porcine growth hormone gene. Gene 55:339-344.

Zimmermann K and Mannhalter JW (1996) Technical aspects of quantitative competitive PCR. BioTechniques 21:268-279.

Associate Editor: André Perondini 